Sri Lanka J. Aquat. Sci. 14 (2009): 29-44

\title{
Distribution and population dynamics of the edible bivalve species Meretrix casta (Chemnitz) in the Dutch canal of Sri Lanka
}

\author{
E.M. JAYAWICKREMA and M.J.S. WIJEYARATNE* \\ Department of Zoology, University of Kelaniya, Kelaniya, Sri Lanka \\ *Corresponding author (E-mail: zoomjs@kln.ac.lk)
}

\begin{abstract}
Meretrix casta is a commercially important clam species in Dutch canal, a slow flowing brackish water body in the western coastal region of Sri Lanka. Its abundance at five sampling sites along a $50 \mathrm{~km}$ stretch of the canal, which ranged from 60 individuals $\mathrm{m}^{-2}$ to 950 individuals $\mathrm{m}^{-2}$, significantly increased with increasing sand, silt and organic matter content of the bottom sediments. Abundance was negatively correlated with the clay content of the sediments. No significant correlation was recorded between the abundance and environmental parameters such as temperature, salinity, $\mathrm{pH}$ and chlorophyll-a content of water. However, abundance was low at the sampling sites with extreme values of salinity ( $<3 \mathrm{ppt}$ and $>40 \mathrm{ppt})$ and $\mathrm{pH}$ $(<8.0$ and $>8.5)$.

Asymptotic length of the clams ranged from $34 \mathrm{~mm}$ to $43.1 \mathrm{~mm}$ and the growth coefficient ranged from 0.84 year $^{-1}$ to 1.44 year $^{-1}$. The ranges for total mortality, natural mortality and fishing mortality coefficients were 2.343.08 year $^{-1}, 0.84-1.44$ year $^{-1}$ and 1.16-2.24 year $^{-1}$ respectively. The highest asymptotic length was recorded at the site where the abundance was the highest. The lowest natural mortality and the highest fishing mortality were also recorded at this site. Environmental parameters at this site were moderate and never reached extreme values indicating optimum conditions for growth and survival. The mean size at first capture $\left(\mathrm{L}_{50}\right)$ ranged from $8.3 \mathrm{~mm}$ to 24.5 $\mathrm{mm}$ while the optimum value for $\mathrm{L}_{50}$ ranged from $13.6 \mathrm{~mm}$ to $23.3 \mathrm{~mm}$. At four sampling sites, present $\mathrm{L}_{50}$ was smaller than the optimum value indicating the exploitation of small individuals. Exploitation rates at two sampling sites were higher than the optimum level indicating overexploitation of the resource at some places along the canal.
\end{abstract}

\section{Introduction}

Meretrix casta is one of commercially important bivalve species abundant in estuaries, backwaters and bays along the coastline of the Indian Ocean (Quasim 1998). In many regions of India, this species contributes for 
the livelihood of large number of fisher families (Pruthi 1999, Anon. 2009). The annual yield of $M$. casta from Maharashtra coast has been estimated to be 5000 tons year ${ }^{-1}$ (Quasim 1998). In Vembanad lake system, which is the largest estuarine system in Kerala, $M$. casta is one of the major species contributing to the clam fishery. From this estuarine system, about 31650 tons of clams are harvested annually (Anon. 2009). In Kali, the largest estuarine system of Uttara Kannada coast, which is well known for clam resources, $M$. casta is one of the major species contributing to clam fishery (Pruthi 1999).

In the Puttalam lagoon and Dutch bay in the north western province of Sri Lanka, six species of edible bivalves have been recorded (Dayaratne et al. 1995). However, only three of these are commercially exploited (Kithsiri 1996). These do not include M. casta. However, in the Dutch canal which is a lotic brackish water body running more or less parallel to the coastline connecting Kelani river and Puttalam lagoon in the western and northwestern provinces of Sri Lanka, the only commercially important bivalve species of Family Veneridae is M. casta (Jayawickrema 1999). Jinadasa et al. (1994) had recorded five species of bivalves in Negombo estuary of which $M$. casta was the most abundant species with a potential harvest of about $10,000 \mathrm{mt}$ per annum.

M. casta is an important test organism which had been widely used to study bioaccumulation and toxicity of heavy metals (Kumaraguru et al. 1980, Patel and Anthony 1991, Karthikeyan and Kumaraswamy 1998, Rajan 1998, Rathabai and Vijayalakshmi 2000, Kumaraswamy et al. 2006) and water soluble fractions of refined and crude oil (Sophia and Balasubramanian 1992). In addition, it could be used as a biological indicator for early detection of pesticide pollution (Devi et al. 2005). It has also been identified as a potential source of antiviral drug as its extracts had shown high antiviral activity when tested with some strains of influenza virus (Chattergi et al. 2002).

Its biology and changes in abundance in some Indian estuaries have been studied in detail (Balasubramaniyan 1993, Harkantra and Rodrigues 2003, Ansari et al. 2007, Arularasan and Kasinathan 2007). It is widely distributed in some brackish water environments in Sri Lanka and is harvested on commercial scale for its shell and flesh (Jayawickrema 1999, Dahanayaka and Wijeyaratne 2006). The shell is used in the lime industry and flesh is used to feed cultured shrimp (Jayawickrema 1999). However, no detail studies are carried out on this species in Sri Lanka. This paper describes the distribution, population dynamics and fishery of $M$. casta in Dutch canal, a slow flowing brackish water body in the north western province of Sri Lanka.

\section{Materials and Methods}

Dutch canal runs along the coastal belt of the western and north western provinces of Sri Lanka more or less parallel to the coastline. It has been 
constructed in the $18^{\text {th }}$ century, connecting the Kelani river to Puttalam lagoon through Negombo and Chilaw lagoons by the Dutch during their colonial regime in Sri Lanka (Infolanka 2009). The $50 \mathrm{~km}$ stretch of the canal running from the Pambala to Madurankuliya $\left(7^{\circ} 30^{\prime}-8^{\circ} 00^{\prime} \mathrm{N}\right.$ and $79^{\circ} 47^{\prime}-80^{\circ} 00^{\prime}$ E) was selected for this study as there is an artisanal fishery for $M$. casta in this region.

Five sampling sites where $M$. casta is commercially exploited were selected at random for this study. Location of these sampling sites is shown in Figure 1. At each sampling site, water temperature, $\mathrm{pH}$, salinity, chlorophyll-a content, soil texture and soil organic matter content were determined monthly for a period of 10 months from October 1998 to July 1999. Due to the shallowness of water $(<0.7 \mathrm{~m}$ in depth), parameters such as temperature, $\mathrm{pH}$, salinity and chlorophyll-a content of water were measured only at the middle of the water column taking samples using a Ruttner sampler. Temperature was measured using a mercury bulb thermometer and salinity was measured using a salinity refractometer. $\mathrm{pH}$ was measured using a portable $\mathrm{pH}$ meter. Three replicates of $500 \mathrm{ml}$ of water samples from each sampling site were filtered through Whatman GFC circles and the filter papers were immediately wrapped in aluminum foil and preserved in ice for transportation to the laboratory at the University of Kelaniya. In the laboratory, the Chlorophyll-content was determined using a spectrophotometer as described by Marker et al. (1980). Soil texture was determined by thoroughly mixing about $10 \mathrm{~g}$ of soil with $50 \mathrm{ml}$ of water in a measuring cylinder and allowing to settle down and then measuring the heights of the silt, clay and sand layers. Soil organic matter content was determined by heating a known weight of a soil sample dried at $100{ }^{\circ} \mathrm{C}$, for 4 hours at $400{ }^{\circ} \mathrm{C}$ in a muffle furnace and determining the weight loss (Ball 1969). Data were statistically analyzed using two way ANOVA and one way ANOVA followed by Tukey's multiple comparison procedure and the correlation coefficients between variables where appropriate (Zar 1996).

Bivalves were sampled using a $1 \mathrm{~m} \mathrm{X} 1 \mathrm{~m}$ quadrate made up of 10 $\mathrm{cm}$ wide metal plates connected to each other from their narrow sides. After placing the quadrate on the bottom in such a way that the metal plates penetrated into the substrate, the bivalves on the bottom within the quadrate were handpicked as much as possible. The bottom substrate within the quadrate was then scooped out to a depth of $10 \mathrm{~cm}$. From each sampling site, 5-7 quadrate samples were taken every month. These samples were then subjected to wet sieving using a $3 \mathrm{~mm}$ mesh and the bivalves in the samples were collected. The number of individuals of $M$. casta in each sample was recorded. Shell length of a minimum of 75 individuals of $M$. casta selected at random from each sampling site was measured every month to the nearest $\mathrm{mm}$ using a Vernier caliper.

Length data were analyzed using FiSAT software package Version 1.0 (Gayanilo et al. 1996) following the procedure described by Amarasinghe and De Silva (1992) and the asymptotic length $\left(\mathrm{L}_{\infty}\right)$, growth coefficient $(\mathrm{K})$ and total mortality coefficient (Z) of M. casta for each sample site were 
determined. The natural mortality coefficient $(\mathrm{M})$ was determined using $\mathrm{M} \approx$ $\mathrm{K}$ approximation (Gayanilo and Pauly 1997). Fishing mortality coefficient (F) was estimated by subtracting $\mathrm{M}$ from $\mathrm{Z}$. The exploitation rates (E) were estimated as F/Z (Gulland 1983). Variation of relative yield per recruit with different $\mathrm{E}$ values was determined using Beverton and Holt model (Beverton and Holt 1966) incorporated in the FiSAT software package. Variation of mean length at first capture/asymptotic length $\left(\mathrm{L}_{50} / \mathrm{L}_{\infty}\right)$ with different $\mathrm{E}$ values was also determined and the optimum $E$ and $L_{50}$ values for each site were estimated.

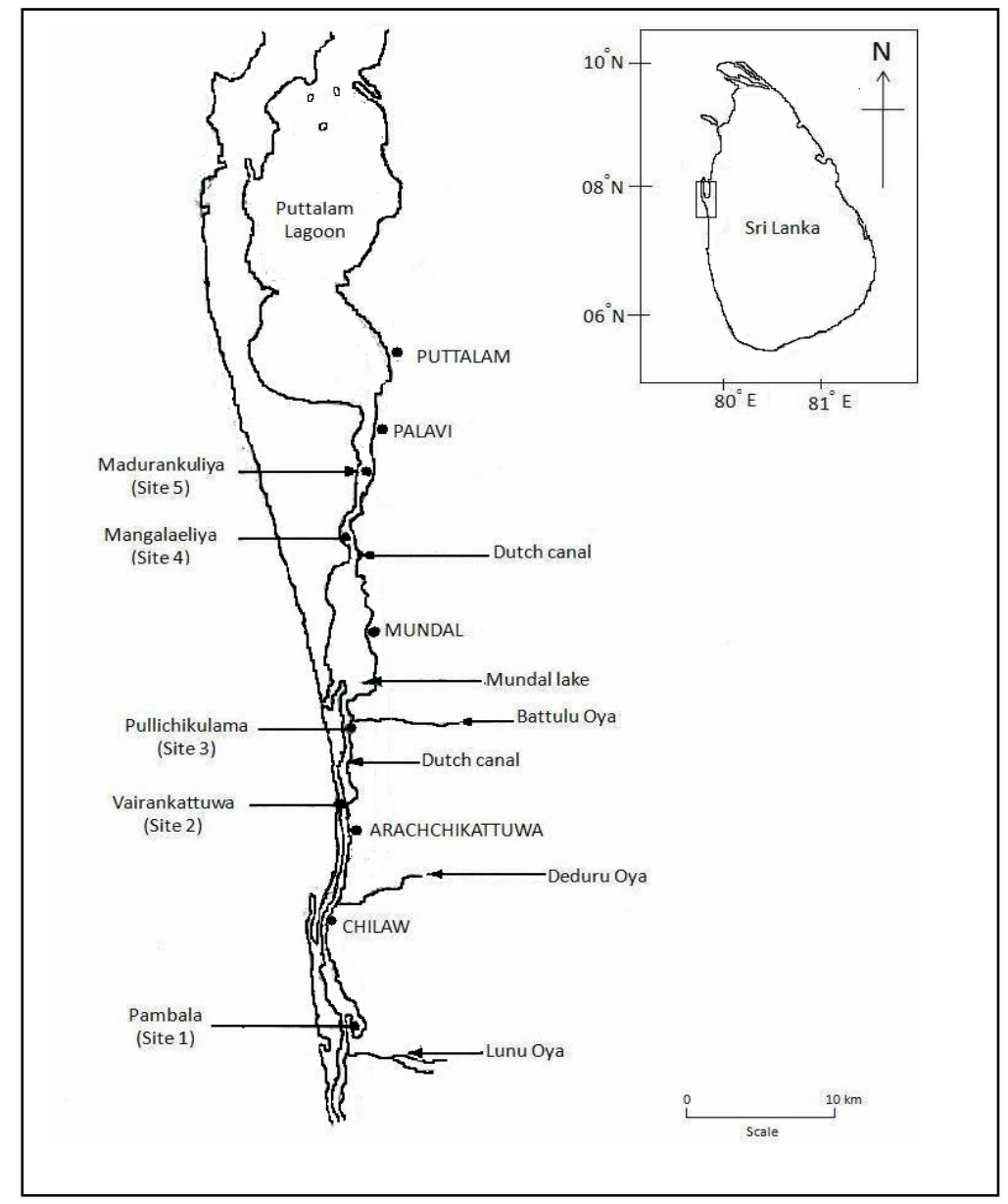

Figure 1. Location of sampling sites

\section{Results}

Monthly variation of water temperature, salinity, $\mathrm{pH}$ and chlorophylla content at each site is graphically shown in Figure 2. Water temperature varied from $28.3{ }^{\circ} \mathrm{C}$ recorded in March and May 1999 at the sampling site 1 to $30.4{ }^{0} \mathrm{C}$ recorded in June 1999 at the sampling site 4. High salinity was 
recorded in all sampling site in September 1998 and the lowest value for salinity, which was $0 \mathrm{ppt}$, was recorded at the sampling sites 1,2 , and 3 in January and May 1999. The highest salinity, which was 43 ppt, was recorded in October 1998 at the sampling site 5. $\mathrm{pH}$ values ranged from 7.1 recorded in May 1999 at the sampling site 5 to 8.8 recorded in June 1999 at sampling site 2. The chlorophyll-a content was high in October and the highest value of $19.9 \mu \mathrm{g} \mathrm{L} \mathrm{L}^{-1}$ was recorded at the sampling site 2 during this month. The lowest value of $0.3 \mu \mathrm{g} \mathrm{L}^{-1}$ was recorded in March at the same sampling site.
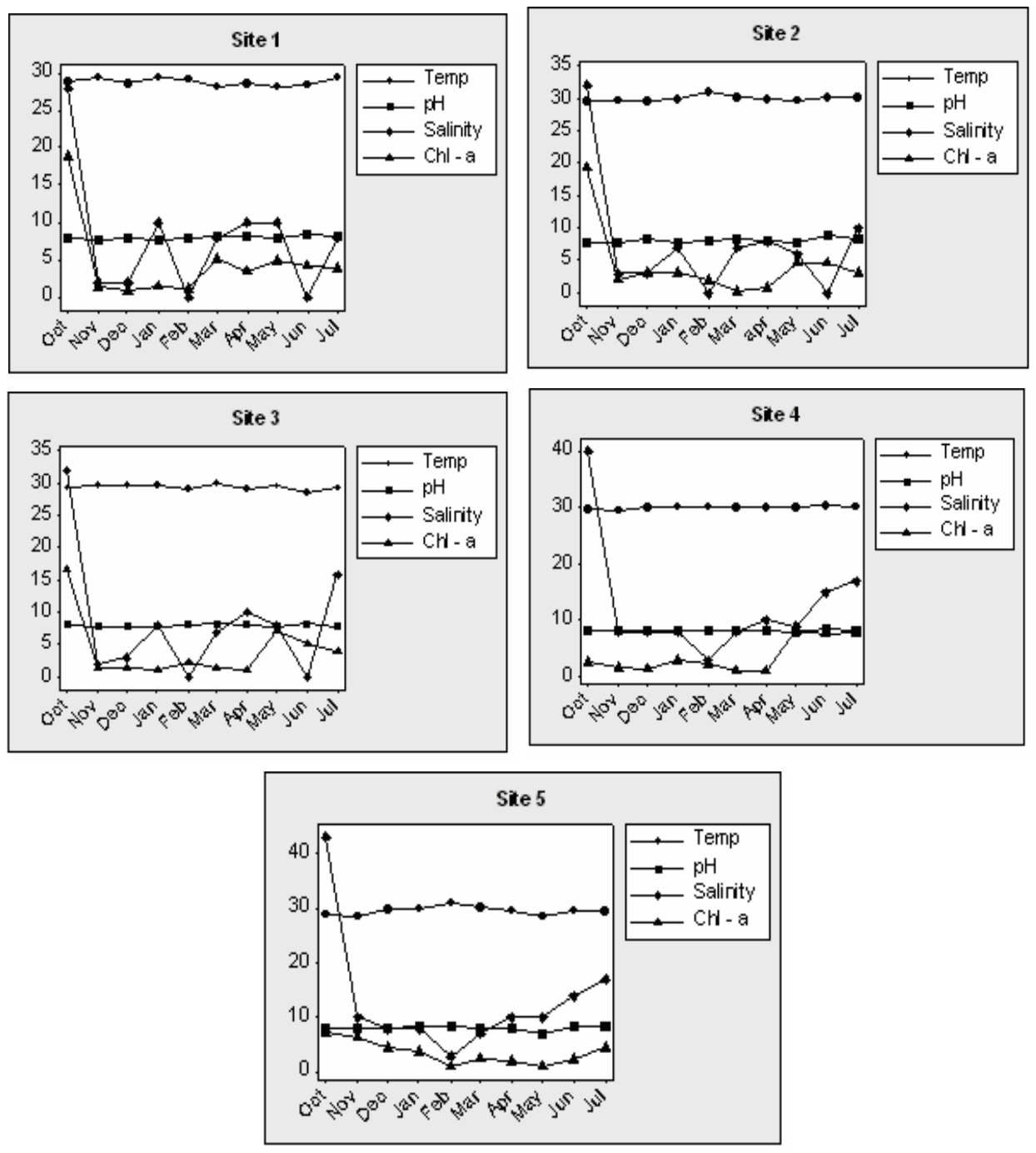

Figure 2. Monthly variation of water temperature $\left({ }^{\circ} \mathrm{C}\right), \mathrm{pH}$, Salinity (ppt) and chlorophyll-a content $\left(\mu \mathrm{g} \mathrm{\textrm {L } ^ { - 1 }}\right)$ at the five sampling sites during the study period. 
Mean monthly values for environmental parameters are given in Table 1. Mean values for percentages of sand, silt and clay in the bottom sediments and abundance of $M$. casta are given in Table 2. Mean water temperature of the Dutch canal in different months was not significantly different from each other $(p>0.05)$. However, mean temperature was significantly lower at the sampling site 1 than at other sites $(\mathrm{p}<0.05)$. Mean values for Chlorophyll-a content and $\mathrm{pH}$ at different sampling sites were not significantly different from each other $(p>0.05)$. Mean salinity at sampling sites 4 and 5 were significantly higher than that of other sites $(\mathrm{p}<0.05)$. In October 1998, chlorophyll-a content and salinity were significantly higher than in other months $(\mathrm{p}<0.05)$. In February, mean salinity was significantly lower than in other months $(\mathrm{p}<0.05)$.

Table 1. Monthly mean values for water temperature salinity $\mathrm{pH}$ and Chlorophyll-a content in the Dutch canal during the study period. Values indicated by some superscript in each column are not significantly different from each other $(\mathrm{p}>0.05)$.

\begin{tabular}{|c|c|c|c|c|}
\hline & $\begin{array}{c}\text { Water } \\
\text { Temperature }\left({ }^{0} \mathrm{C}\right) \\
\end{array}$ & $\begin{array}{c}\text { Salinity } \\
\text { (ppt) }\end{array}$ & pH & $\begin{array}{l}\text { Chlorophyll-a } \\
\text { content }\left(\mu \mathrm{g} \mathrm{L}^{-1}\right)\end{array}$ \\
\hline October 1998 & $29.3^{\mathrm{a}}$ & $35.0^{\mathrm{a}}$ & $8.02^{\mathrm{ab}}$ & 13.0 \\
\hline November & $29.5^{\mathrm{a}}$ & $5.0^{\text {bd }}$ & $7.96^{\mathrm{ac}}$ & $2.6^{\mathrm{b}}$ \\
\hline December & $29.6^{\mathrm{a}}$ & $4.8^{\mathrm{bd}}$ & $8.06^{\mathrm{ab}}$ & $2.3^{\mathrm{b}}$ \\
\hline January 1999 & $29.9^{\mathrm{a}}$ & $8.2^{\mathrm{b}}$ & $8.00^{\mathrm{ab}}$ & $2.5^{\mathrm{b}}$ \\
\hline February & $30.2^{\mathrm{a}}$ & $1.2^{\mathrm{d}}$ & $8.10^{\mathrm{a}}$ & $1.8^{\mathrm{b}}$ \\
\hline March & $29.8^{\mathrm{a}}$ & $7.4^{\mathrm{b}}$ & $8.20^{\mathrm{ab}}$ & $2.1^{\mathrm{b}}$ \\
\hline April & $29.5^{\mathrm{a}}$ & $9.6^{\text {be }}$ & $8.12^{\mathrm{a}}$ & $1.7^{\mathrm{b}}$ \\
\hline May & $29.3^{\mathrm{a}}$ & $8.6^{\mathrm{b}}$ & $7.76^{\mathrm{c}}$ & $5.2^{\mathrm{b}}$ \\
\hline June & $29.5^{\mathrm{a}}$ & $5.8^{\text {bd }}$ & $8.48^{\mathrm{b}}$ & $4.8^{\mathrm{b}}$ \\
\hline July & $29.8^{\mathrm{a}}$ & $13.6^{\mathrm{ce}}$ & $8.16^{\mathrm{a}}$ & $4.7^{\mathrm{b}}$ \\
\hline
\end{tabular}

Mean values for $\%$ sand in different sampling sites varied from $82 \%$ to $89 \%$ while $\%$ silt content varied from $2 \%$ to $8 \%$ (Table 2 ). The $\%$ clay content was $8-10 \%$. There was no significant difference in the mean values for percentages of sand, clay and silt among sampling sites $(\mathrm{p}>0.05)$. The $\%$ organic matter content in the bottom sediments ranged from $4.2 \%$ to $6.5 \%$. Mean value for \% organic matter content was significantly higher in sampling site 2 than in other sampling sites $(\mathrm{p}<0.05)$.

Mean abundance of $M$. casta varied from 60 individuals $\mathrm{m}^{-2}$ recorded at sampling site 3 to 950 individuals $\mathrm{m}^{-2}$ recorded at sampling site 4 (Table 2). Its mean abundance in sampling site 3 was significantly lower than in other sites whereas the abundance at sampling site 4 was significantly higher than in other sites $(\mathrm{p}<0.05)$. 
Table 2. Mean values for water temperature, salinity, $\mathrm{pH}$ and Chlorophyll-a content of water; $\%$ organic matter, $\%$ sand, $\%$ clay and $\%$ silt contents in bottom sediments and abundance of bivalves at each sampling site. Values indicated by the same superscript in each row are not significantly different from each other at $5 \%$ level of significance.

\begin{tabular}{lccccc}
\hline & Site 1 & Site 2 & Site 3 & Site 4 & Site 5 \\
\hline Water Temperature $\left({ }^{0} \mathrm{C}\right)$ & $28.9^{\mathrm{a}}$ & $30.1^{\mathrm{b}}$ & $29.5^{\mathrm{b}}$ & $30.1^{\mathrm{b}}$ & $29.6^{\mathrm{b}}$ \\
Salinity (ppt) & $8.7^{\mathrm{a}}$ & $8.3^{\mathrm{a}}$ & $9.6^{\mathrm{a}}$ & $13.3^{\mathrm{b}}$ & $13.7^{\mathrm{b}}$ \\
$\mathrm{pH}$ & $8.0^{\mathrm{a}}$ & $8.1^{\mathrm{a}}$ & $8.0^{\mathrm{a}}$ & $8.2^{\mathrm{a}}$ & $8.1^{\mathrm{a}}$ \\
Chlorophyll-a content $\mu \mathrm{g} \mathrm{L}{ }^{-1}$ & $4.5^{\mathrm{a}}$ & $4.3^{\mathrm{a}}$ & $4.2^{\mathrm{a}}$ & $3.7^{\mathrm{a}}$ & $3.9^{\mathrm{a}}$ \\
\% organic matter & $4.3^{\mathrm{a}}$ & $6.5^{\mathrm{b}}$ & $4.8^{\mathrm{a}}$ & $4.6^{\mathrm{a}}$ & $4.5^{\mathrm{a}}$ \\
\% sand & $88^{\mathrm{a}}$ & $89^{\mathrm{a}}$ & $86^{\mathrm{a}}$ & $85^{\mathrm{a}}$ & $82^{\mathrm{a}}$ \\
\% clay & $8^{\mathrm{b}}$ & $9^{\mathrm{b}}$ & $9^{\mathrm{b}}$ & $9^{\mathrm{b}}$ & $10^{\mathrm{b}}$ \\
\% salt & $4^{\mathrm{a}}$ & $2^{\mathrm{a}}$ & $5^{\mathrm{a}}$ & $6^{\mathrm{a}}$ & $8^{\mathrm{a}}$ \\
Abundance $\left(\right.$ No. $\left./ \mathrm{m}^{2}\right)$ & $240^{\mathrm{a}}$ & $520^{\mathrm{d}}$ & $60^{\mathrm{b}}$ & $950^{\mathrm{e}}$ & $360^{\mathrm{c}}$ \\
\hline
\end{tabular}

Correlation coefficients between the abundance of $M$. casta and environmental parameters are given in Table 3. The abundance of $M$. casta was not significantly correlated with salinity, $\mathrm{pH}$ and Chlorophyll-a content ( $p>0.05$ ). However, significant correlations were evident between the abundance of $M$. casta and sand, silt, clay and organic matter contents of the bottom sediments $(\mathrm{p}<0.002)$. The abundance was positively correlated with the sand, silt and organic matter contents while a negative correlation was evident with the clay content (Table 3).

Table 3. Correlation coefficients between the abundance of $M$. casta and some environmental parameters

\begin{tabular}{lccc}
\hline Environmental parameter & $\begin{array}{c}\text { Correlation } \\
\text { coefficient }\end{array}$ & $\mathbf{N}$ & $\mathbf{p}$ \\
\hline Salinity & -0.12 & 75 & $>0.05$ \\
pH & -0.10 & 75 & $>0.05$ \\
Chlorophyll-a & -0.14 & 75 & $>0.05$ \\
\% Sand & 0.38 & 75 & $<0.001$ \\
\% Silt & 0.29 & 75 & $<0.002$ \\
\% Clay & -0.27 & 75 & $<0.002$ \\
\% Organic matter & 0.40 & 75 & $<0.001$ \\
\hline
\end{tabular}

Length frequency distributions of $M$. casta at the five sampling sites together with estimated growth curves are shown in Figure 3. The $\mathrm{L}_{\infty}, \mathrm{K}$, $\mathrm{Z}, \mathrm{M}$ and $\mathrm{F}$ values for $M$. casta at different sampling sites are given in Table 4. The highest $L_{\infty}, Z$ and $F$ values and the lowest $K$ and $M$ values were recorded at sampling site 4 . The lowest $L_{\infty}$ was recorded at sampling site 2 while the lowest $Z$ value was recorded at sampling site 3 . The highest $K$ and $M$ values and lowest $F$ values were recorded at sampling site 1 (Table 4). 

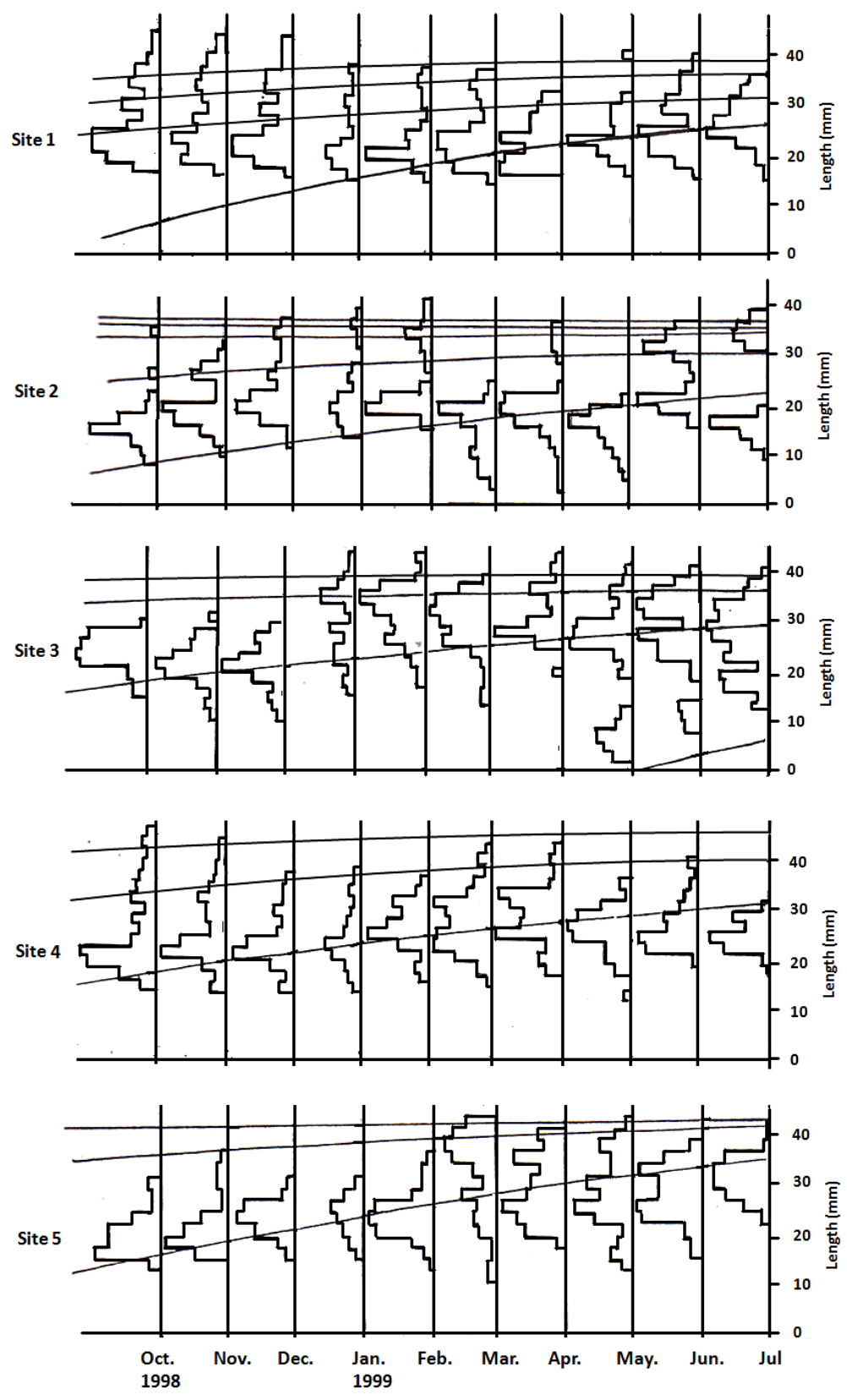

Figure 3. Length frequency distribution of Meretrix casta at the five sampling sites together with estimated growth curves.

Present exploitation rate (E), present mean length at first capture $\left(\mathrm{L}_{50}\right)$, optimum exploitation rate $\left(\mathrm{E}_{\mathrm{opt}}\right)$ and optimum mean length at first capture $\left(\mathrm{L}_{\mathrm{opt}}\right)$ at each sampling site are given in Table 5. Present exploitation rates at sampling sites 1 and 5 were found to be lower than the optimum level where as at sampling sites 2 and 4, the present E values were higher than the 
optimum values. At sampling site 3, present $\mathrm{E}$ value was more or less equal to the optimum value. Present $L_{50}$ values at sampling sites 1, 2, 4 and 5 were smaller than the optimum values and at sampling site 3 , it was higher than the optimum value.

Table 4. Asymptotic length $\left(\mathrm{L}_{\infty}\right)$, Von Bertalanfly growth coefficient $(\mathrm{K})$, total mortality coefficient $(\mathrm{Z})$, natural mortality coefficient $(\mathrm{M})$ and fishing mortality coefficient (F) of $M$. casta at each sampling site.

\begin{tabular}{lrrrrr}
\hline Parameter & Site 1 & Site 2 & Site 3 & Site 4 & Site 5 \\
\hline $\mathrm{L}_{\infty}(\mathrm{mm})$ & 38.2 & 34.0 & 41.1 & 43.1 & 36.3 \\
$\mathrm{~K}\left(\right.$ year $\left.^{-1}\right)$ & 1.44 & 0.88 & 1.12 & 0.84 & 1.34 \\
$\mathrm{Z}\left(\right.$ year $\left.^{-1}\right)$ & 2.60 & 2.48 & 2.34 & 3.08 & 2.73 \\
$\mathrm{M}\left(\right.$ year $\left.^{-1}\right)$ & 1.44 & 0.88 & 1.12 & 0.84 & 1.34 \\
$\mathrm{~F}\left(\right.$ year $\left.^{-1}\right)$ & 1.16 & 1.60 & 1.22 & 2.24 & 1.39 \\
\hline
\end{tabular}

Table 5. Present exploration rate $(\mathrm{E})$, present mean length at first capture $\left(\mathrm{L}_{50}\right)$, optimum exploration rate $\left(\mathrm{E}_{\mathrm{opt}}\right)$ and optimum mean length at first capture $\left(\mathrm{L}_{\text {opt }}\right)$ at each samples site.

\begin{tabular}{lccccc}
\hline Parameter & Site 1 & Site 2 & Site 3 & Site 4 & Site 5 \\
\hline $\mathrm{E}$ & 0.5 & 0.7 & 0.5 & 0.7 & 0.5 \\
$\mathrm{~L}_{50}(\mathrm{~mm})$ & 16.1 & 8.3 & 24.7 & 17.0 & 13.7 \\
$\mathrm{E}_{\text {opt }}$ & 0.7 & 0.5 & 0.5 & 0.6 & 0.6 \\
$\mathrm{~L}_{50 \text { opt }}(\mathrm{mm})$ & 22.2 & 13.6 & 16.0 & 23.3 & 20.0 \\
\hline
\end{tabular}

\section{Discussion}

Dutch canal is a commercially important lotic water body as it is the source of water for nearly $70 \%$ of the shrimp farms in Sri Lanka. About 850 ha of shrimp farms are located on either side of the canal. Shrimp farm effluents are also discharged into this canal which has resulted in various problems such as the spread of shrimp diseases and environmental degradation (Dayaratne et al. 1995, Corea et al. 1995, 1998, Siriwardene 2001).

In the past, fish, crustaceans and mollusks had been exploited from this canal on a commercial scale (Corea et al. 1995). Today, fish and crustaceans are harvested on a subsistence level and the bivalve $M$. casta is harvested on a commercial scale. In some places such as Pambala (Sampling site 1), M. casta is harvested throughout the year while in other areas (Sampling sites 2, 3, 4 and 5), it is harvested only from February to July. The monthly catch at each site had been estimated to be 13-30 mt (Jayawickrama 1999). 
It has been reported that environmental parameters such as salinity, temperature, sediment texture and organic matter content in the sediments significantly contribute to the abundance of bivalves (Lee 1972). However, during the present study, the abundance of $M$. casta in the Dutch canal was not found to be significantly correlated with salinity and water temperature ( $p$ $>0.05)$. The ranges for salinity and water temperature observed in the Dutch canal, i.e., $0-3 \mathrm{ppt}$ and $28.3-30.4^{\circ} \mathrm{C}$ respectively, may not have a significant influence on the survival and mortality of this species. Narasimham and Laxmilatha (1996) had also reported that $M$. casta could tolerate prolonged low salinities. It has also been reported that $M$. casta is not affected by salinities above 40 ppt (Thangavelu and Poovannam 1994). As observed by Ranade (1964), in low salinities $M$. casta may have closed their valves tightly and borrowed into the substrate to survive and the abundance may not have changed significantly with the variation in salinity from $0 \mathrm{ppt}$ to $43 \mathrm{ppt}$.

The observed variation in water temperature in the Dutch canal also appears to be too narrow to bring about a significant change in the population size of $M$. casta. Therefore, a significant correlation between the abundance and water temperature could not have been observed. The $\mathrm{pH}$ in the Dutch canal also changed within a narrow range, i.e., from 7.1 to 8.8 during the study period. This range also appears to be tolerated well by $M$. casta. Although chlorophyll-a content in water varied within a wide range from 0.3 $\mu \mathrm{g} \mathrm{\textrm {L } ^ { - 1 }}$ to $19.9 \mu \mathrm{g} \mathrm{L} \mathrm{L}^{-1}$, abundance of $M$. casta was not observed to be significantly correlated with it. Chlorophyll-a content in water is an indicator of abundance of green algae, hence with algal productivity in the water column. However, it appears that the abundance of $M$. casta does not depend on the algal productivity of the water column.

Although the percentages of sand, silt and clay varied in a narrow range, results indicated that the abundance of $M$. casta was significantly correlated with those environmental factors. The abundance increased with increasing sand and silt contents and decreased with increasing clay content indicating that this species preferred benthic habitats with high amounts of sand and silt. Narasimham and Laxmilatha (1996) also reported that M. casta thrived on sandy bottoms. Cahn (1951) reported that best substrates for bivalves usually contained $60-90 \%$ sand. Silt in a water body results in due to settling down of suspended particles which mainly derive from land based activities. Silt levels in the Dutch canal had increased over the past years mainly due to the effluents discharged from nearby shrimp farms (Corea et al. 1998). These effluents, in addition to containing large amounts of silt, are enriched with nutrients due to decomposition of organic matter such as unutilized food, wastes of shrimp etc. These nutrients may be adsorbed to silt particles resulting in an increase in abundance of these benthic animals with increasing amounts of silt in the benthic sediments.

In the Puttalam lagoon and Dutch bay, located slightly north of the study area (Figure 1), the abundance of bivalves was reported to be highly correlated with the substrate condition (Kithsiri 1996). However, M. casta was not recorded in these water bodies although they are contiguous with the 
Dutch canal. One of the reasons for this may be the high clay content in the sediments which is above $15 \%$ (Kithsiri 1996). In all sampling sites of the Dutch canal, the clay content was found to be less than $15 \%$.

The abundance of $M$. casta was found to be positively correlated with the organic matter content in the substrate. It has been reported the organic detritus contributes to a larger proportion of the diet of bivalve mollusks (Fraga and Vives 1960). Therefore, it appears that the increase in the abundance of the bivalve $M$. casta with increasing amounts of organic matter in the bottom sediments is due to availability of more food

$\mathrm{L}_{50}$ of $M$. casta was highest at sampling site 4 . At this site, $\mathrm{K}$ value was the lowest. $\mathrm{K}$ is a measure of the rate achieving $\mathrm{L}_{\infty}$. When $\mathrm{L}_{\infty}$ is large, more time is taken to reach it. Hence $\mathrm{K}$ becomes low. $\mathrm{L}_{\infty}$ of $M$. casta in Negombo lagoon had been estimated to be $40 \mathrm{~mm}$ (Jinadasa et al. 1999). In Muthukadu backwaters in India it has been estimated to be $42 \mathrm{~mm}$. The values for $L_{\infty}$ estimated at sampling sites 1,2 and 5 during the present study were less than $37 \mathrm{~mm}$ and at other two sampling sites it was above $41 \mathrm{~mm}$.

The highest $\mathrm{L}_{\infty}$, which was $43.1 \mathrm{~mm}$ was recorded at sampling site 4 where the abundance was also the highest. It appears that environmental conditions at this site are highly favorable for $M$. casta. Although abundance was not significantly correlated with $\mathrm{pH}$ and salinity, this site recorded the highest mean salinity of $13.3 \mathrm{ppt}$ and the highest mean $\mathrm{pH}$ of 8.2. In none of the months, the salinity at this sampling site was below 3 ppt or above 40 ppt. Similarly, $\mathrm{pH}$ at this sampling was always between 8.0 and 8.5. Therefore, these ranges appear to be the most desirable for the growth and survival of $M$. casta in the Dutch canal. In addition, the abundance of $M$. casta was found to be significantly correlated with sand, silt and clay contents in bottom sediments. These benthic characteristics may be also have been most favourable at this site because the highest abundance was recorded there. The natural mortality was also found to be the lowest at this sampling site, possibly due to favourable environmental conditions. The highest fishing mortality was observed at this sampling site indicating high fishing pressure. This may also be due to high abundance and presence of large individuals at this site.

At sampling sites 1 and 2, where $\mathrm{L}_{\infty}$ was $38.2 \mathrm{~mm}$ and $34.0 \mathrm{~mm}$ respectively, salinity was 0 ppt in some months. At the sampling site 5 where $\mathrm{L}_{\infty}$ was $36.3 \mathrm{~mm}$, the mean salinity was $13.7 \mathrm{ppt}$ and in some months it reached a value as high as $43 \mathrm{ppt}$. In addition, in some months, $\mathrm{pH}$ was 7.1. These extreme values may have affected the growth of $M$. casta in these sites resulting in low $\mathrm{L}_{\infty}$. Natural mortality was also found to be high at sampling sites 1 and 5, possibly due to those extreme environmental conditions. However, at sampling site 2, although $\mathrm{L}_{\infty}$ was the lowest, natural mortality was found to be low. More studies on ecological relationships are needed to explain this. The lowest abundance of $M$. casta was observed at sampling site 3. Even though the abundance of $M$. casta was not found to be correlated with salinity, at this sampling site, salinity was 0 ppt in two months and $2 \mathrm{ppt}$ in another month. These extreme environmental conditions may have 
contributed to low survival of $M$. casta at this site resulting in low abundance. However, even with extreme environmental conditions, $\mathrm{L}_{\infty}$ was estimated to be $41.1 \mathrm{~mm}$ at this sampling site. To explain this also more studies are needed. Possibly a combination of other environmental factors may have contributed to this high $\mathrm{L}_{\infty}$.

Yield per recruit analysis indicated that $M$. casta populations at sampling sites 2 and 4 are over-exploited and the fishing effort has to be reduced by about $30 \%$ and $15 \%$ of the present level respectively. However, at sampling sites 1 and 5, there is a possibility to increase the fishing effort by about $40 \%$ and $20 \%$ of the present level respectively to obtain the maximum sustainable yield. At sampling site 3, the exploitation rate was more or less at the optimum level. At the sampling sites 1,2, 4 and 5, present $\mathrm{L}_{50}$ is smaller than the optimum value and therefore it appears that small individual are harvested at these sites. Hence it is necessary to increase the $\mathrm{L}_{50}$ at these sites. At the sampling site 3 , present $\mathrm{L}_{50}$ is higher than the optimum value and there is a possibility to catch smaller individuals than those caught at present.

M. casta resource in Dutch canal is very useful to sustain the shrimp farming industry in the area. In addition to providing meat to be used as shrimp feed, it also reduces the suspended solids in shrimp farm effluents (Liyanage et al. 1998). In addition, their shells are used in lime kilns. The clam resource is important economically too as it provides an additional income to the fisher community. Therefore, harvesting this resource at the maximum sustainable level without over-exploitation is very important. A proper management procedure, with the participation of stakeholder community is therefore needed. For such a management procedure, the findings of this study would be very useful.

\section{References}

Amarasinghe, U.S. \& S.S. De Silva 1992.

Population dynamics of Oreochromis mossambicus and O. niloticus (Pisces: Cichlidae) in two reservoirs in Sri Lanka. Asian Fisheries Science 5: 57-61.

Anonymous 2009.

Conventions and treaties (International conventions). Available from: http://casmbenvis.nic.in/sdnp/convention.htm (Accessed on $8^{\text {th }}$ May 2009).

Ansari Z.A., S. Sivadas \& B.S. Ingole 2007.

Benthic macrofauna. In: The Mandovi and Zuari Estuaries (S.R. Shetye, M. Dileepkumar \& D. Shankar eds.), pp 91-98, Available from: http://hdl.handle.net/2264/631 (Accessed on 10 ${ }^{\text {th }}$ May 2009).

Arularasan, S. \& R. Kasinathan 2007.

Molluscan composition at Vellar estuary, Portonovo coast. Zoo print Journal 22 (1): 2546. Available from: http://www.Zoosprint.org/ 
zooPrint Journal/2007/January/2546.pdf (Accessed on $10^{\text {th }}$ May 2009).

Balasubramaniyan, K. 1993.

Breeding biology of Meretrix casta (Chemnitz) (Mollusca: Bivalvia) from Vellar estuary. In: Proceedings of the National Symposium on Aquaculture Development in India: Problems and Prospects (P. Natarajan \& V. Yayapraras eds), pp 131-134, Thiruvananthapuram, India.

Ball, D.F. 1964.

Loss on ignition as an estimate of organic mater and organic carbon in soils. Journal of Soil Science 15:18-92.

Beverton, R.J.H \& S.J. Holt 1966.

Manual of Methods for Fish stock Assessments. Part II- Table of Yield Functions. FAO Fisheries Technical Paper 38: 1 - 67.

Cahn A.R. 1951.

Clam Culture in Japan. Fisheries leaflet No. 399. US Fish and Wildlife Services. 103 p.

Chattergi, A., Z.A. Ansari, B.S. Ingole, M.A. Bichurina, M. Sovetova \& Y.A. Boikov 2002.

Indian marine bivalves: Potential source of antiviral drugs. Current Science 82 (10): $1279-1282$

Corea, A.S.L.E., J.M.P.K. Jayasinghe, S.U.K. Ekaratne \& R. Johnstone 1995. Environmental impacts of prawn farming on the Dutch canal. Ambio 24: $423-427$.

Corea, A.S.L.E., J.M.P.K. Jayasinghe, S.U.K. Ekaratne, R. Johnstone \&

G.M.J. Jayawardene 1998.

Autopollution: A major threat to the shrimp farming industry in Sri Lanka. Ambio 27 (8): 628-662.

Dahanayaka, D.D.G.L. and M.J.S. Wijeyaratne 2006.

Diversity of macrobenthic community in the Negombo estuary with special reference to environmental conditions. Sri Lanka Journal of Aquatic Sciences 11: $43-62$.

Dayaratne, P., O. Lindon \& M.W.R.N. De Silva 1995.

Puttalam lagoon in Sri Lanka: A study of coastal resources, their utilization, environmental issues and management options. Ambio 24: 391-401.

Devi, K.P., S.K. Pandian \& N.S.S. Kumar 2005.

Cholinesterase activity in clam Meretrix casta: Possible biomarker for organophosphate pesticide pollution. Bulletin of Environmental Contamination and Toxicology 74 (2): $250-255$.

Fraga, F. \& F. Vives 1960.

Retention of particulate matter. In: Marine Mussels: Their Ecology and Physiology (B.L. Bayne ed.) pp 13 - 65, Cambridge University Press, U.K.

Gayanilo, F.C. Jr. \& D. Pauly 1997. 
FAO-ICLARM Stock Assessment Tools (FiSAT) Reference Manual, FAO, Rome. 220 p.

Gayanilo, F.C. Jr., P. Sparre \& D. Pauly 1996.

FAO-ICLARM Stock Assessment Tools (FISAT) User's Manual. FAO, Rome. 185 p.

Gulland, J.A. 1983.

Fish Stock Assessment: A Manual of Basic Methods. FAO/ Wiley

Series on Food and Agriculture. John Wiley, Chichoester, UK.

Harkantra, S.N. \& N.R. Rodrigues 2003.

Pattern of species succession of soft bottom macrofauna in the estuaries of Goa, west coast of India. Current Science 85 (10): 1458 1474. Available from: http://hdl.handle.net/2264/305 (Accessed on $10^{\text {th }}$ May 2009).

Infolanka 2009.

Dutch waterways in Sri Lanka Available from: http://www.infolanka.com/ org/srilanka/hist/hist11/htm/ (accessed on $11^{\text {th }}$ May 2009).

Jayawickrema, E.M. 1999.

Distribution, Population Dynamics and Fishery of the Edible Bivalve Species Meretrix casta (Chemnitz) in the Dutch Canal of the North Western Province of Sri Lanka. M.Sc. Thesis, University of Kelaniya, Sri Lanka. 110 p.

Jinadasa J., W.E.M.K. Ekanayaka and M. Furst 1994.

Preliminary observations on clam distribution, and on maturity size and fishing of Meretrix casta in the Negombo lagoon. In: Proceedings of the $50^{\text {th }}$ Annual Scientific Sessions of Sri Lanka Association for Advancement of Science. Part I

Karthikeyan, A. \& P. Kumaraswamy 1998.

Effects of sub-lethal concentrations of cadmium on biochemical constituents of an estuarine clam Meretrix casta (Chemnitz) under different salinities. Journal of Environment and Pollution 5 (1): 13 16.

Kithsiri, H.M.P. 1996.

Distribution, Population Dynamics and Fishery of Three Species of Bivalves (Family: Veneridae) in the Puttalam Lagoon and Dutch Bay, Sri Lanka. M. Phil. Thesis, University of Kelaniya, Sri Lanka. $121 \mathrm{p}$.

Kumaraguru, A.K., D. Selvi \& V.K. Venugopalan 1980.

Copper toxicity to an estuarine clam. (Meretrix casta). Bulletin of

Environmental Contamination and Toxicology 241: 853 - 857.

Kumaraswamy, P., K. Muthukumaravel, S.V.S.A. Hameed \& R. Rajendran 2006.

Effects of some heavy metals on the filtration rate of an estuarine clam Meretrix casta (Chemnitz). Indian Journal of Environmental Sciences 10 (1): $79-80$. 
Lee, C. 1972.

An ecological study on some marine bivalve beds of Korean tide lands. In: Proceedings of the Indo-Pacific Fisheries Council $13^{\text {th }}$ Sessions, pp. 326-331, Brisbane, Australia.

Liyanage, G.L.S.N., W.M.T.B. Wanninayake \& U. Edirisinghe 1998.

Feasibility of using bivalve mollusks to reduce suspended solid content in shrimp farm effluents. Sri Lanka Journal of Aquatic Sciences 3: $43-49$.

Marker, A.F.H., C.A. Crowther \& J.M. Gunn 1980.

Methanol and acetone as solvents for estimating chlorophyll-a and phaeopigments by spectrophotometry. Archiv für Hydrobiologie (Supplement) 14: 52-69.

Narasimham, K.A. \& P. Laxmilatha 1996.

Clam culture. Bulletin of Central Marine Research Institute 68: 7687.

Patel, B. \& K. Anthony 1991.

Uptake of cadmium in tropical marine lamellibranchs and effect on physiological behaviour. Marine Biology 108 (3): 457 - 470).

Pruthi, J.S. 1999.

Quick Freezing Preservation of Foods. Allied Publishes Limited. New Delhi, India. 622 p.

Quasim, S.Z. 1998.

Glimpses of the Indian Ocean. Orient Blackswan 206 p. Available from: http://books.google.lk (Accessed on $10^{\text {th }}$ May 2009).

Rajan, A. 1998.

Bioaccumulation of manganese in Meretrix casta (Chemnitz). In: Advances and Priorities in Fisheries Technology, pp. 262-368, Society of Fisheries Technologists (India), Cochin, India.

Ranade M.R. 1964.

Studies on biology, ecology and physiology of marine clams. Ph.D. Dissertation, University of Bombay, India.

Rathabai, V. \& K. Vijayalakshmi 2000.

Changes in heavy metal concentration in relation to season and stages of clam Meretrix casta. Journal of Ecotoxicology and Environmental Monitoring 10 (2): 93 - 96.

Siriwardene P.P.G.S.N. 2001.

Shrimp aquaculture: Its associated problems. In: Proceedings of the Workshop on Effective Management for Biodiversity Conservation in Sri Lankan coastal Wetlands: Muthurajawela Marsh, Negombo Lagoon and Chilaw Lagoon (N. Farmer ed.), pp. 55 - 65, centre for Economics and Management of Aquatic Resources, University of Portsmouth, U.K.

Sophia A.J.A. \& T. Balasubramanian 1992.

Changes in physical condition of Meretrix casta exposed to water soluble fraction of refined and crude oil. Archives of Environmental Contamination and Toxicology 24(4): 471 - 474. 
Thangavelu, R \& P. Poovannam 1994.

On some aspects of biology of the clam Meretrix casta in Muttukadu backwaters. Journal of Marine Biological Association of India. 36(1,2): $77-80$

Zar, J.H. 1996.

Biostatistical Analysis, Prentice-Hall Inc., Englewood Cliffs. New Jersey. $718 \mathrm{p}$. 